\title{
PENYALAHGUNAAN DADAH DAN KEWAJARAN PERUNTUKAN HUKUMAN MATI KE ATAS PENGEDAR DADAH DI MALAYSIA: SATU ANALISIS
}

\author{
Azman Mohd Noor* \\ Mohd Al-Ikhsan bin Ghazali**
}

\begin{abstract}
Drug is the country's no one enemy. Drug abuse has caused a lot of social problems, crimes and wasted many of youth's lives who are supposed to be the futere asset to the country. The goverment has spent a lot of money to set up rehabilitation centres, provide facilties and means of rehabilitative treatement for the drug addicts. This paper will investigate Islamic rulings for drug abuse and drug trafficking and the justifications for imposing capital punishment for the drug trafficker.
\end{abstract}

Keywords: drug abuse, drug trafickier, strick punishment, Islamic law

\section{PENYALAHGUNAAN DADAH MENURUT PERSPEKTIF ISLAM}

Masalah penyalahgunaan dadah adalah gejala penyakit masyarakat yang paling merbahaya sekarang. Ia menyerang semua lapisan

* Assistant Prof. at Department of Fiqh and Usul al-Fiqh, Kuliyyah of Islamic Revealed Knowledge and Human Sciences, International Islamic University Malaysia, azmann@iium.edu.my

* Lecturer at Department Islamic Studies, Univeristi Teknologi Malaysia. 
masyarakat khususnya golongan muda. Dadah melemahkan kekuatan ekonomi dan melumpuhkan pembangunan negara dengan meracuni pemikiran dan semangat individu untuk memantapkan diri dengan keperluan semasa dan cabaran masa hadapan. Dadah boleh dianggap punca segala jenis jenayah dan maksiat seperti merompak, mencuri, memeras ugut dan lain-lain jenayah yang membawa kekacauan dalam rumah tangga, masyarakat dan negara. Di samping itu penagih dadah adalah beban kepada negara. Kerajaan terpaksa menghabiskan duit berjuta-juta ringgit setahun untuk menanggung kos pusat-pusat pemulihan. Pada masa yang sama pengedar mengaut keuntungan berganda-ganda daripada penderitaan penagih yang setia.

Sejak dahulu lagi umat Islam ditegah daripada meminum perkara-perkara yang memabukkan. Islam mengharamkan sesuatu yang memabukkan bagi tujuan menjaga akal, kesihatan tubuh badan dan melindungi individu dan anggota masyarakat keseluruhannya. Dengan kata lain, Islam mengharamkan perkaraperkara yang memabukkan kerana kemudaratan yang disebabkan olehnya. Kemudaratan ini melibatkan diri penagih pada 'aqalnya, tubuh badannya, pembaziran harta dan kerosakan hubungan keluarga dan tidak menunaikan suruhan agama. Ia tidak terbatas pada dirinya sahaja tetapi menyusahkan masyarakat dan umat keseluruhannya. ${ }^{1}$

Tidak ada dalil yang jelas menyebut perkataan dadah dan pengharamannya. Ini kerana masalah ini baru berlaku. Umat Islām hanya mengenali dadah pada kurun ke tujuh Hijrah selepas kemasukan Kerajaan Tartar. $^{2}$

Begitu juga tiada dalil yang sarih yang menunjukkan bahawa dadah itu haram seperti arak. Kedua-duanya dianggap najis oleh sebahagian besar umat Islām. Pun begitu, terdapat segelintir umat Islam yang mengambil kesempatan berseronok dengan dadah atau bekerja keras mengaut keuntungan daripada perniagaan dadah.

1 Yūsuf Ḥāmid al-Ālim (1994), al-Maqāṣid al-'Ammah li al-Syarī‘ ah al-Islämiyyah. Virginia: The International Institute of Islamic Thought, hh.376-387.

2 Bahansi, Ahmad Fathi (1969), Al-Mas'ūliyyah al-Jinā'iyyah fì alFiqh al-Islāmī. Beirut: Mu'assasah Ḥalabi, h. 227. 
Rasulullah telah diberikan jawāmi' al-Kalim di mana katakatanya yang sedikit mempunyai maksud yang banyak. Dalil yang digunakan oleh ulama bagi pengharaman dadah adalah berdasarkan kaedah-kaedah dan prinsip-prinsip yang digunakan untuk mengambil hukum daripada al-Qur'ān atau hadis.

\section{Pengharaman Dadah Berdasarkan Nas}

Banyak hadis Rasulullah yang menunjukkan haramnya dadah. Di antaranya hadis Ummu Salamah yang diriwayatkan oleh Imām Aḥmad dan Abū Dāwūd’

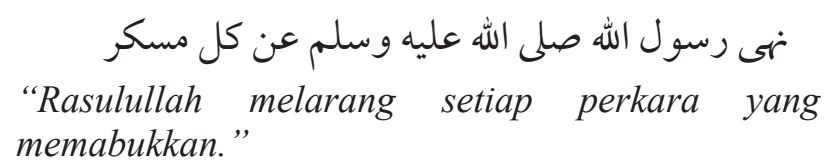

Dalam hadis lain sebagaimana yang diriwayatkan oleh Jabir, Rasulullah bersabda: ${ }^{4}$

$$
\text { ما أسكر كثيره فقليله حرام }
$$

"Apa-apa saja yang memabukkan adalah haram banyak ataupun sedikit."

Tidak syak lagi bahawa dadah boleh membunuh manusia sedangkan Allah melarang segala perbuatan yang boleh menyebakan kemusnahan diri. Samalah juga haram bagi orang Islām memakan atau meminum sesuatu yang boleh menyebabkan kebinasaan pada dirinya apabila diketahuinya.

\section{Pengharaman Dadah Kerana ia Merangkumi Madlūl Lafaz}

3 Aḥmad, al-Masānid, Baqi Musnad al-Anwār, Hadīth no.25416. Lihat juga Abū Dāwūd, al-Sunan, Kitab al-Asyribah, Hadīth no.3201. Hadis tidak diberi apa-apa komentar oleh Abu Dawud dan didaifkan oleh al-Albani.

4 Al-Tirmizi, Sunan, Kitāb al-Asyribah, hadis no. 5891. Hadis hasan gharib, Abū Dāwūd, al-Sunan, Kitāb al-Ashribah, hadis no.3196. Hadis tidak diberi apa-apa komentar oleh Abū Dāwūd, al-Nasā' $\overline{1}, a l-$ Sunan, Kitāb al-Asyribah, hadis no.5513 dan Ahmad, al-Masanid, Musnad al-Muksirīn, hadis no.5390. 


\section{Khamr}

Para ulama menggunakan lafaz khamr bagi semua benda yang meninggalkan kesan kepada akal selepas pengambilannya. Ini adalah berdasarkan maksudnya yang umum daripada segi bahasa. Pada asalnya perkataan khamr bererti tutup dan perkara yang menutup akal (memabukkan) dan menghilangkan kesedaran dipanggil khamr kerana ia menutup akal dan menghalangnya daripada berfungsi seperti biasa. ${ }^{5}$ Dalilnya ialah hadis yang diriwayatkan oleh Imām Muslim: ${ }^{6}$

$$
\text { كل مسكر خم وكل مسكر حرام }
$$

"Setiap yang memabukkan adalah khamr dan setiap khamr adalah haram"

Walaupun pengikut mazhab Abū Ḥanīfah mengehadkan nama khamr kepada arak yang dibuat daripada anggur, mereka bersepakat dengan jumhur dalam mengharamkan semua benda yang memabukkan. Ia adalah haram tanpa mengira bentuknya sama ada jenis cair atau debu atau pepejal. Pengharamannya bukanlah kerana zatnya tetapi kerana kemudaratannya. ${ }^{7}$

Yūsuf al-Qaraḍ̄āî juga telah memberi fatwa pengharaman dadah seperti marijuana, kokain, dan ganja dan lain-lain yang memabukkan dan mengkhayalkan. Beliau telah menggolongkan dadah di bawah khamr yang diharamkan. ${ }^{8}$

5 Muhammad 'Alī al-Syawkānī (t.t), Nayl al-Auțār. Beirut: Dār alKutub al-'Ilmiyyah, juz 7, h. 49.

6 Al-Bukhārī, al-Ṣaḥịh, Kitāb al-Asyribah, hadis no. 5147. Lihat juga al-Muslim, al-Șah̄ịh, Kitāb al-Asyribah, hadis no. 3733, dan Ibn Hajr, Bulugh al-Maram, hadis no. 1070, h.397.

7 Ibn 'Abidīn (1996), Hasyiyah Ibn 'Abidīn. Beirut: Dār al-Fikr, juz 5, h. 453.

8 Yūsuf al-Qaraḍāwī (1994), al-Halāl wa al-Harām fì al-Islām, Kamāl al-Helbāwī (terj.), The Lawful and the Prohibited in Islam, Kuala Lumpur: Islamic Book Trust, h. 76. 


\section{Pengharaman Dadah Melalui Kaedah Qiyās}

Sesetengah 'ulamā'menggunakankaedahqiyāsuntukpengharaman arak. Mereka mengqiyāskan dadah dengan khamr (arak). Keduaduanya mempunyai 'illah yang sama iaitu kerana berbagai kemudaratan yang berlaku seperti memabukkan, merosakkan anggota badan dan punca kepada maksiat dan jenayah lain. ${ }^{9}$

\section{Pengharaman Dadah Berdasarkan Maqāṣsid (Matlamat) Sharīah}

Ada pula mengharamkan dadah berdasarkan kaedah daf $u$ alDarar wa daf' $u$ al-mafāsid. Islām adalah agama yang memelihara kepentingan asasi manusia iaitu agama, akal, nyawa, harta dan keturunan. Semua perkara yang boleh mengancam perkaraperkara penting ini diharamkam oleh Syarak. Dadah bukan sahaja merosakkan akal tetapi juga nyawa, harta, keturunan dan agama. ${ }^{10}$

Semua dalil dan hujah di atas menunjukkan haramnya penyalahgunaan dadah sama ada menagih atau menjualnya bagi tujuan tersebut.

Ibn Taymiyyah berpendapat bahawa penyalahgunaan dadah digolongkan di bawah kesalahan hudüd. Hujahnya ialah dadah adalah haram seperti arak. Dengan itu pengambilannya juga adalah haram. Penagih mestilah dihukum sebat atas kesalahan $h u d \bar{u} d$ kerana ianya lebih keji daripada arak. Tambahan pula dadah merosakkan akal fikiran dan mengubah tabiat badan sehingga menjadi khayal dan dayus bagi lelaki dan juga membawa berbagai mafsadah. ${ }^{11}$

9 Muḥammad Fatḥ̄ 'Aid (1988), Jarīmah Ta'atī al-Mukhaddirāt fì alQānūn al-Muqāran. Riyadh: Markaz 'Arabi, Dirāsah Amniyyah wa Tadrīb, h. 374.

10 Ibid., h. 376.

11 Ibn Taymiyyah, al-Siyāsah al-Shar 'iyyah, hh. 116-117. 


\section{HUKUM MENGEDAR DADAH MENURUT PANDANGAN SYARAK}

Apabila Islam mengharamkan sesuatu perkara seperti daging babi, semua perkara yang berkait seperti menjual, mengangkut dan membekal adalah haram. Semua perantaraan yang membawa kepada tujuan haram adalah haram. Samalah juga dengan kes dadah. Hukum berniaga ataupun mengedar dadah adalah haram berdasarkan larangan jual beli arak ${ }^{12}$.

Rasulullah dalam satu hadis yang diriwayatkan oleh Jābir melarang keras jual-beli perkara haram:

$$
\text { إن الله ورسوله حرم بيع الخمر والميتة والخنزير والأصنام }
$$

"Sesungguhnya Allah dan Rasulnya mengharamkan

jual beli arak, bangkai, babi dan berhala." 13

Para 'ulamà' juga bersetuju mengatakan bahawa adalah haram hukumnya menanam pokok-pokok yang menghasilkan bahanbahan dadah dan haram memperolehi hasil jualannya. ${ }^{14}$

Dadah dengan bermacam-macam jenisnya dan kesan-kesan kimia yang ditinggalkan boleh menyebabkan kematian dan ini adalah satu cara pembunuhan. Dengan itu, pengedar dadah secara tidak langsung boleh dianggap sebagai pembunuh kerana dia memberikan bahan yang boleh membunuh mangsanya (penagih). Mungkin mereka boleh berhujah bahawa penagih ada

12 'Izzah Ḥusnayn (1990), Mausū'ah al-Muskirāt wa al-Mukhaddirah al-Jadìdah. Mesir: Maktabah Sayyid 'Abdullah Wahbah, 'Abbasiyyah, h. 148. Perniagaan dadah yang diharamkan di sini, merujuk kepada urusan jual beli dan membekalkan dadah bagi tujuan yang diharamkan iaitu penagihan dan pengambilan untuk berkhayal, memabukkan dan membinasakan. Kerana matlamatnya haram, wasilahnya juga haram sebagaimana haramnya menanam anggur bagi tujuan membuat arak.

13 Al-Bukhārī, al-Ṣaḥịh, Kitāb al-Buyū', hadis no. 2082, Muslim, alȘaḥ̄h, Kitāb al-Musāqāt, hadis no. 2960. Lihat juga al-Ḥāiz Ibn Ḥajr al-'Asqalānī (1996), Bulūgh al-Maram min Adillati al-Aḥkām. Riyadh: Dār al-Salam, h. 239.

14 Al-Jazirī. 'Abd al-Raḥmān (t.t.), al-Fiqh 'Alā Madhāhib al-Arba'ah. Beirut: Dār al-Kutub al-'Ilmiyyah, jil. 5, hh. 38-42. 
pilihan dan pengambilan dadah adalah di atas dasar kehendak mereka sendiri. Soal pilihan penagih ini adalah dosanya sendiri. Tetapi penagih tidak akan menderita tanpa wujudnya dadah. Dia bagaikan terpaksa atas desakan syahwat yang tinggi yang tidak terkawal untuk mendapatkan bahan tersebut. Manakala pengedar pula mengaut keuntungan yang berlipatkali ganda. Perlu diingat bahawa seseorang dikira membunuh apabila dia memberikan racun untuk membunuh seseorang.

'Abd al-Qadīr 'Audah menjelaskan di dalam mazhab Māliki, seseorang yang memberi racun kepada orang lain apabila mangsa mengetahui keadaan itu ia dianggap membunuh diri tetapi jika mangsa tidak mengetahui ia dianggap membunuh dengan sengaja. Imām Aḥmad pula berpendapat sekiranya seseorang memberi racun kepada orang lain tanpa pengetahuannya ia dianggap membunuh dengan sengaja jika racun itu biasanya menyebabkan kematian. Tetapi kalau kebiasaannya ia tidak mengakibakan kematian ia boleh dikira membunuh "quasi-intentional" (shibh al- 'amd). ${ }^{15}$

Dengan itu bolehlah dirumuskan bahawa pengedar dadah tidak terlepas daripada kesalahan menyebabkan kematian ke atas mangsanya di samping menimbulkan huru hara dan gejala jenayah lain yang berpunca daripada dadah. Dengan itu, hukuman yang setimpal ialah hukuman mati. Secara khususnya, boleh dirumuskan bahawa pengedar dadah melakukan dua kesalahan. Pertama, menyebabkan kematian kepada penagih dengan membekalkan dadah yang membinasakannya. Kedua, mendapat keuntungan dengan bayaran yang mahal di sebalik penderitaan penagih. Pendapatan yang lumayan itu adalah hampir sama dengan merompak dan merampas harta orang lain secara paksa.

\section{PERUNTUKAN HUKUMAN MATI KE ATAS PENGEDAR DADAH DI MALAYSIA}

Berdasarkan kepada undang-undang yang diperuntukkan dalam akta, seksyen 39B Akta Dadah Berbahaya 1952 (Pindaan) 1983 Akta A533 dengan jelas menyebut hukuman mati mandatori ke atas pengedar dadah yang disabitkan kesalahannya.

15 'Abd al-Qadīr 'Audah, al-Tasyrì' al-Jinā'ī, jil. 2, h. 76. 
Sebelum pindaan dibuat oleh seksyen 14 Akta Dadah Berbahaya (Pindaan) 1983 Akta A533, peruntukan 39B(2) Ordinan 1952 seperti yang dipinda oleh seksyen 7 Akta Dadah Berbahaya (pindaan) 1975 Akta A293 ialah hukuman mati dalam bentuk pilihan kepada penjara seumur hidup. Tetapi selepas pindaan dibuat oleh seksyen 14 Akta Dadah Berbahaya (Pindaan) 1983 Akta A533, hukuman mati di dalam seksyen 39B(2) Ordinan Dadah Berbahaya 1952 seperti yang dipinda oleh seksyen 7 Akta Dadah Berbahaya (Pindaan) 1975 Akta A293 menjadi hukuman mandatori. ${ }^{16}$

Di antara faktor yang menyebabkan pemerintah Malaysia menjatuhkan hukuman mati mandatori ke atas pengedar dadah berbahaya adalah seperti berikut:

(a) Kerajaan Malaysia telah mengganggap masalah dadah sebagai musuh utama negara yang dikira lebih merbahaya daripada komunis. Dadah boleh meruntuhkan masyarakat, hubungan keluarga, melumpuhkan ekonomi dan menghapuskan agama, menghancurkan negara dan melenyapkan bangsa dan negara.

(b) Negara Malaysia sedang menghadapi wabak penagihan dadah yang serius yang menjadi sasaran utama ialah golongan muda sebagai harapan bangsa dan negara pada masa depan. Bahkan wabak ini telah menjalar di kalangan anggota keselamatan dan kakitangan awam yang ditugaskan untuk menjaga keselamatan dan menguruskan pentadbiran negara. Kesannya ialah hilang kecekapan, terdedah kepada risiko rasuah dan penyelewengan, rahsia negara tidak selamat dan membuka peluang kepada musuh. ${ }^{17}$

(c) Dadah menimbulkan pelbagai perbuatan jenayah dan maksiat lainnya seperti perompakan, pencurian, pemerasan, pembunuhan yang pada akhirnya mengancam ketenteraman dan keselamatan negara.

16 Hashim bin Mehat (1987), "Undang-Undang Jenayah Satu Penilaiaan Dalam Hukuman Utama”, (Kertas Kerja Seminar Undang-undang dan Masyarakat, UKM, Bangi, 5 September 1987), h.5.

17 Abdul Ghafar Taib (1988), Dadah, Strategi dan Kawalan di SekolahSekolah. Kuala Lumpur: Dewan Bahasa dan Pustaka, hh. 65-66. 
(d) Pengedar dadah merupakan manusia kejam yang membunuh dan menyiksa penagih dadah dalam jangka panjang. Mereka hanya mementingkan wang atas penderitaan orang lain. Maka adalah wajar sebagai pembunuh, mereka dibunuh pula.

(e) Bahawa dengan menetapkan hukuman mati mandatori pada tahun 1983, bertujuan menghapuskan ketidakadilan dalam menjatuhkan hukuman yang sebelumnya iaitu pilihan antara hukuman mati atau penjara seumur hidup atau sebat. Hukuman mandatori sebagai alternatif adalah samarata. ${ }^{18}$

(f) Jika hukuman mati masih menjadi pilihan kepada hukuman penjara seumur hidup, ada kebarangkalian hakim lebih cenderung untuk memilih hukuman penjara seumur hidup. Ini menyebabkan gejala pengedaran dadah terus berleluasa kerana para pengedar masih memperjudikan nasib mereka.

\section{HUKUMAN MATI KE ATAS PENGEDAR DADAH DALAM ISLAM}

Adakah hukuman mati yang dijatuhkan oleh undang-undang Malaysia bertentangan dengan undang-undang Islam? Apakah hukuman yang sepatutnya dikenakan ke atas pengedar dadah mengikut pandangan Islam? Persoalan ini akan terjawab sekiranya kita betul -betul memahami undang-undang Islam.

Dalam kes Pendakwaraya lwn. Che Omar bin $\mathrm{Che} \mathrm{Soh}^{19}$ rayuan dibuat atas dasar hukuman mati mandatori adalah bertentangan dengan hukuman Islam yang merupakan agama rasmi bagi Persekutuan. Walau bagaimanapun Hakim Negara Tun Salleh Abbas menjelaskan maksud sebenar perkataan "rasmi" ialah bagi tujuan upacara dan adat-adat keagamaan sahaja. Yang peliknya peguam bela kepada tertuduh iaitu Ramdas Tikamdas bukanlah seorang Muslim, tetapi berhujah mengungkitkan kedudukan agama Islam sebagai agama rasmi. Sejauh manakah hukuman itu bertentangan dengan Islam akan dikaji dalam perbincangan ini.

18 Waluyaningsih (1997), Hukuman Mandatori Bagi Pesalah Dadah di Malaysia dan Republik Indonesia. Kuala Lumpur: Dewan Bahasa dan Pustaka, hh. 65-66.

19 1988,2 M.L.J. 55 
Terdapat perbezaan pendapat di kalangan ulama untuk menentukan hukuman mati ke atas pengedar dadah sama ada ia adalah $t a^{6} z \bar{\imath} r$ ataupun hudiud. Perbezaan pendapat ini adalah khilaf lafzī dari sudut kedua-duanya memutuskan hukuman mati ke atas pengedar. Tetapi, perbezaan pendapat ini menentukan perbezaan teknikal dan pelaksanaan hukuman ke atas tertuduh di atas kesalahan mengedar dadah. Penulis akan membincangkan perbezaan ini kemudian.

\subsection{Hukuman Mati ke Atas Pengedar Berdasarkan Hukuman Hudūd}

Penagih dadah boleh dikaitkan dengan kesalahan meminum arak iaitu sebat sebanyak 40 kali. Bagaimana pula dengan pengedar dadah. Kebanyakan ulama mengaitkan kesalahan mengedar dadah dengan kesalahan hirābah. Sehubungan dengan hal tersebut, Surah al-Mā'idah ayat 33 adalah dasar peruntukan hukuman mati bagi kesalahan dadah, khususnya penyeludup dan pengedar dadah.

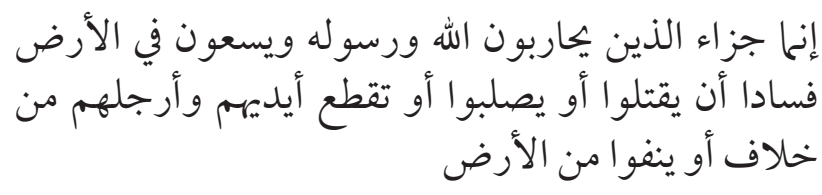

"Sesungguhnyan balasan bagi mereka yang melakukan Hirābah (rompakan dan kerosakan (kefasadan) di atas muka bumi ialah hukuman bunuh, palang sampai mati, potong tangan dan kaki secara bersilang ataupun dibuang negeri."

Surah al-Mā'idah: 33

Ayat tersebut dan ayat sebelumnya tidak hanya ditujukan kepada Bani Israel, tetapi juga kepada umat manusia seluruhnya kerana terdapat ungkapan dalam ayat ini yang menyebut "manusia seluruhnya".

Oleh itu, bolehlah dikatakan bahawa kesalahan dadah dapat dimasukkan dalam kriteria yang pada akhirnya "membunuh manusia" yang seolah-olah bererti telah "membunuh manusia seluruhnya". Secara tidak langsung kesalahan dadah juga bererti akan "membuat kerosakan di bumi". Dengan yang demikian, 
kesalahan mengedar dadah boleh dimasukkan dalam klasifikasi kesalahan $h u d \bar{u} d$. Ini kerana ia akan membahayakan kepentingan dan keselamatan umum. Dengan itu adalah wajar jika penjenayah yang terlibat dengan penyeludupan dan pengedaran dadah dikenakan hukuman mati berdasarkan kepada ayat di atas.

Al-Qurțubī berpendapat bahawa ungkapan "memerangi Allah dan Rasulnya" memberi erti metafora atau majāz kerana tidak ada sesiapapun boleh memerangi Allah S.W.T. yang menjadikan manusia keseluruhannya. Maknanya ialah memerangi auliya 'Nya dan masyarakat dengan menyamakan perbuatan permusuhan dengan Allah untuk menunjukkan betapa besarnya kesalahan tersebut. $^{20}$

Imām al-Shaukānī menjelaskan bahawa apa yang dimaksudkan dengan ifs $\bar{a} d$ ialah apa sahaja pengertian yang dapat difahami sebagai melakukan kerosakan seperti syirik, menyamun, menumpahkan darah manusia, menceroboh kehormatan, merampas harta, melakukan pembunuhan, meruntuhkan bangunan, memotong pokok kayu mengubah sungai (menghalang orang lain daripada mendapatkan air) semua itu termasuk dalam pengertian ifsād fi al-'ard . ${ }^{2 l}$

Di antara ulama mutakhir yang menggolongkan kesalahan mengedar dadah di bawah ifsād fi al-ard atau hirābah ialah alHusayni Sulaymān Jad. ${ }^{22}$ Beliau berpendapat bahawa kesalahan mengedar dadah adalah satu kesalahan yang berat yang boleh digolongkan di bawah kesalahan tersebut.

Daripada pandangan-pandangan 'ulam $\bar{a}$ ' yang diberikan dapatlah disimpulkan bahawa al-hirābah mempunyai pengertian dan madlül yang luas yang meliputi semua jenis perbuatan yang dikira melakukan kerosakan di atas muka bumi. Walaupun jenis jenayah kerosakan tidak disebut dengan jelas semuanya boleh diqiyaskan dengan kesalahan hirābah. Dengan itu pengedaran

20 Muḥammad ibn Aḥmad al-Qurțubī (1993), al-Jāmi' li Aḥkām alQur'ān. Beirut: Dār Ihyya' al-Turāth al-'Arabi, jil. 6, h. 150.

21 Muhammad 'Alī al-Syawkānī (1964), Tafsīr Fath al-Qadīr. Kaherah: Maktabah Bābi al-Halabī, jil. 2 h. 32.

22 Sulaymān Jad al-Husayni (1991), al-'Uqūbah al-Badaniyyah fì alFiqhi al-Islāmī, Dustūriyyatuha wa 'Alaqatuha bi al-Difa' al-Syar'i. Mesir: Dār al-Syurūk, h. 224. 
dadah boleh dikategorikan kepada kesalahan "ifsād fì al-'ard" salah satu daripada kesalahan hudūd.

Di dalam hirāabah, sekiranya perompak membunuh mangsanya maka dia dikenakan hukuman mati. Sekiranya dia merompak sahaja dia dikenakan hukuman potong tangan dan kaki bersilang. Sekiranya dia menakutkan sahaja tanpa merompak seperti mengacukan senjata hukuman buang negeri akan dikenakan ke atasnya. Sesetengah ulama pula berpendapat bahawa ia terpulang kepada imām untuk menentukan hukuman berdasarkan kemaslahatan umum. Dia boleh mengenakan hukuman mati ke atas pesalah jika itu satu mașlahah seperti ketua atau 'master mind' kumpulan perompak walaupun dia tidak melakukan pembunuhan dalam rompakan tersebut. ${ }^{23}$

Kesalahan mengedar dadah banyak persamaannya dengan kesalahan hirābah dari sudut menyebabkan kerosakan dan malapetakadiatasmukabumi. Iaboleh dikaitkan denganmemerangi Allah dan RasulNya kerana dadah boleh menghancurkan ummat Islam khasnya dan ummat manusia amnya. Hukuman mati ke atas pengedar dadah dengan itu merupakan hukuman hudīd kerana banyak persamaan pengedaran dadah dengan hirābah. ${ }^{24}$

Dari sudut lain pengedar dadah yang menyebabkan kematian kepada penagih telah melakukan kesalahan jenayah yang besar dan berhak mendapat hukuman yang setimpal dengan kesalahan yang dilakukan. Ini kerana dalam Islam, hukuman bagi kesalahan membunuh atau menyebabkan kematian kepada orang lain ialah qișāṣ atau bunuh balas.

\subsection{Hukuman Mati ke Atas Pengedar Dadah Berdasarkan Hukuman $\mathrm{Ta}^{6} z \overline{\boldsymbol{i}} \boldsymbol{r}$}

Sebagaimana yang telah dibincangkan kesalahan $t a^{6} z \bar{r} r$ adalah kesalahan yang selain daripada kesalahan hudūd atau qișāss. Hukuman $t^{6} z \bar{r}$ merupakan hukuman yang tidak ditetapkan oleh Sharā' dan terpulang kepada pemerintah untuk menentukan kadar dan bentuk hukuman. Hakim diberi pilihan untuk mengenakan

23 Ibn Taymiyyah, op.cit., h. 87.

24 Abdirazak Mohamud Takar (1998), "Capital Punishment for Drug Trafficking”, (Disertasi MCL, UIA), h.33. 
hukuman yang setimpal bagi setiap kesalahan daripada yang paling ringan sehingga kepada yang paling berat.

Al-Jazīrī berpendapat bahawa pemerintah boleh mengenakan hukuman $t a^{6} z \bar{\imath} r$ ke atas mereka yang melakukan kesalahan yang tidak dikategorikan dalam $h u d \bar{u} d$ atau qișāṣ atau kaffarah. Hukuman yang boleh dikenakan termasuk dengan memenjara atau sebat. Ulama berselisih pendapat tentang bilangan sebatan. Sebahagian ulama Hanafī, Mālikī dan Ibn Taymiyyah membolehkan hukuman mati dalam $t a^{6} z \bar{l} r$ untuk kesalahan berat yang boleh mengganggu kemaslahatan umum ${ }^{25}$.

Berdasarkan temubual ${ }^{26}$ penulis dengan beberapa orang pensyarah di Universiti Islam Antarabangsa Malaysia, seperti Professor Dr. Abdalla M.K. Al-Jubburi daripada Fakulti Ilmu Wahyu, Prof. Dr. Mohammad Hashim Kamali dan Prof. Dr. Syed Misbahul Hassan daripada Fakulti Undang-undang, semuanya menolak pendapat bahawa hukuman mati ke atas pengedar dadah adalah kesalahan hudūd di bawah had hirābah . Di sebaliknya mereka bersetuju meletakkan hukuman mati bagi kesalahan mengedar dadah di bawah kesalahan ta'zir yang melibatkan hukuman mati berdasarkan pandangan Imām Mālik dan sesetengah Hanabilah yang berpendapat hukuman $t a^{6} z \bar{r} r$ yang maksimum ialah hukuman mati. ${ }^{27}$

Dalam menghuraikan masalah adakah undang-undang mandatori bertentangan dengan Islām, Prof. Dr. Said Misbahul Hasan menjawab dalam keadaan tertentu kerajaan dibolehkan menggubal undang-undang yang dianggap dapat menyelesaikan permasalahan yang serius seperti mengedar dadah. Dasar ini adalah di bawah konsep al-Siyāsah al-Shar'iyyah yang mengutamakan kemașlahatan umum.

Jawatankuasa Fatwa, Majlis Kebangsaan Bagi Hal Ehwal Agama Islam memutuskan bahawa kesalahan mengedar dadah yang boleh membawa kepada hukuman mati mandatori adalah di bawah kategori hukuman $t a^{6} z \bar{i} r$.

25 Al-Jazìrī, op.cit., jil. 7, h. 397.

26 Temubual ini dilakukan sendiri oleh penulis pada $3 \mathrm{hb}$. Julai $1999 \mathrm{di}$ UIA..

27 Bahansī, Naẓariyyāt fì al-Fiqhi al-Jinā' $\bar{\imath}$, h. 182. 
"Hukuman mati ke atas pengedar dadah boleh dikenakan sekiranya pemerintah berpendapat yang demikian itu membawa kebaikan kepada masyarakat."

Keputusan ini dibuat apabila ada perselisihan pendapat sama ada hukuman mati 39B tersebut menepati hukuman Syarak atau tidak. Beberapa kaedah fiqh dikemukakan sesuai dengan kes ini:

i. Nisbah perbuatan kepada kesan akan datang membawa kepada kerosakan qat? $\bar{\imath}$.

ii. Pengurusan pemerintah dengan urusan rakyat adalah berdasarkan kemașlahatan.

iii. Melakukan yang lebih ringan daripada dua dararayn. ${ }^{28}$

Keputusan yang dibuat oleh Majlis Fatwa adalah sama dengan keputusan yang dibuat oleh Majlis Ulama Arab Saudi. Majlis Ulama Arab Saudi dalam pertemuan mereka di Riyadh pada 9-20.6.1407 telah membincangkan hukuman yang sepatutnya dikenakan ke atas pengedar dadah. Hasil daripada pertemuan itu mereka telah mengeluarkan resolusi hukuman mati ke atas pengedar dadah. Alasan mereka ialah kerana pengedar dadah menyebar penyakit dan menimbulkan kesan-kesan negatif yang merbahaya kepada masyarakat keseluruhannya.

Walau bagaimanapun, mereka telah membahagikan pengedar dadah kepada dua kategori. Yang pertama ialah pengedar utama yang membawa masuk dadah daripada luar negara. Mereka dikenakan hukuman mati $t a^{6} z \bar{l} r$. Yang kedua pula ialah penjual dadah yang menyampaikan dadah kepada penagih. Hukuman ke atas penjual dadah adalah berbeza. Bagi pesalah yang pertama kali ditangkap hukuman berat $t a^{6} z \bar{r} r$ seperti penjara, sebat dan denda dikenakan. Bagi pesalah yang berulang atau melakukan kesalahan yang berat hukuman mati $t a^{6} z \bar{\imath} r$ boleh dijatuhkan ke atasnya. ${ }^{29}$

28 "Hukuman Bunuh ke Atas Pengedar Dadah", (Kertas Kerja Jawatankuasa Fatwa Kebangsaan, 12 Jamadil Akhir, 1404 bersamaan 15 Mac 1984)..

29 Majallah Majma' al-Fiqhī al-Islāmī: Bahagian 1, jil. 2, hh. 221-222, nukilan daripada Abdirazak Mohamud Takar, "Capital Punishment for Drug Trafficking”, h. 29. 
Kalau hendak diaplikasikan konsep hukuman $t a^{6} z \bar{i} r$ dalam kes jenayah mengedar dadah di Malaysia, nampaknya hukuman yang diperuntukkan dalam Akta Dadah Berbahaya adalah bertepatan dengan hukuman $t a^{6} z \bar{\imath} r$. Ini kerana setiap hukuman dikenakan berdasarkan kadar jenayah dan berat (gram) dadah yang dimiliki oleh tertuduh. Manakala hukuman yang berat sekali ialah hukuman mati.

Perbezaannya ialah hukuman $t a^{6} z \bar{l} r$ boleh dikenakan ke atas tertuduh yang sudah dikenali dengan kejahatannya walaupun ada sedikit keraguan pada bahan bukti. ${ }^{30}$

Begitu juga dalam menetapkan kadar (nisab) maksimum 15 gram heroin mestilah dengan penuh ketelitian. Bukti-bukti dan keterangan lain perlu juga diambil kira untuk memastikan yang tertuduh benar-benar melakukan kesalahan tersebut.

Penulis berpendapat bahawa kesalahan mengedar dadah adalah dikategorikan di bawah kesalahan $t a^{6} z \bar{\imath} r$. Di antara hujah-hujah yang menyokong pendapat ini ialah:

1. Hudīd adalah kesalahan yang telah disebut dengan jelas hukumannya samada dalam al-Quran atau hadis. Persoalannya bolehkah kaedah qiyās digunakan dalam menjatuhkan hukuman adalah satu masalah yang perlu diambil kira. Ulama telah bersepakat boleh mengunakan kaedah qiyās untuk menjatuhkan hukuman $t a^{6} z \bar{\imath} r$ bagi kesalahan jenayah yang baru. Tetapi mereka berselisih pendapat menggunakan kaedah qiyās bagi kesalahan hudūd. Jumhur ulama seperti Mālikiyah, Shāfi'iyyah dan Hanābilah berpendapat boleh melaksanakan hukuman hudūd dengan qiyās. Hanafiyah pula menolak penggunaan kaedah qiyās dalam hukuman bagi kesalahan yang hampir sama dengan $h u d \bar{u} d^{31}$.

Penulis lebih cenderung menggolongkan kesalahan penyalahgunaan dadah di bawah ta'zir kerana penggunaan kaedah qiy $\bar{a} s$ pada kesalahan $t a^{6} z \bar{\imath} r$ dipersetujui tanpa khilaf. Tambahan pula kesalahan hudūd dipanggil hudūd kerana ia

30 Al-Ghāmidī, 'Uqūbah al-I'dām, Riyadh: Maktabah Dār aI-Islām, h.30.

31 'Abd al-Karīm bin 'Alī Muhammad Namlah (1410), Ithbāt al'Uqūbah bi al-Qiyās. Riyāḍ: Maktabah al-Rusyd, h. 94. 
telah ditetapkan. 'Ulam $\bar{a}$ ' telah bersepakat meletakkan beberapa kesalahan tertentu di bawah hudūd. Dengan itu amatlah tidak munasabah untuk meletakkan kesalahan jenayah yang baharu berlaku di bawah hudūd.

2. Kalau hendak diqiyaskan penyalahgunaan dadah dan hukuman ke atas pengedar dadah seperti kesalahan meminum arak, hukuman hudūd (sebat) wajib dikenakan ke atas peminum arak tidak pula ke atas penjual atau pembekal arak. Tetapi pemerintah boleh mengambil tindakan undang-undang ke atas peniaga arak dengan alasan hukuman $t a^{6} z \bar{\imath} r$ bukannya hudūd walaupun hukuman yang dikenakan ke atasnya hukuman sebat. Samalah juga dengan pengedar dadah hukuman yang dikenakan ialah hukuman $t a^{6} z \bar{r} r$ berdasarkan kadar seriusnya kesalahan mengedar dadah.

3. Ulama bersepakat hukuman sebat yang dikenakan ke atas peminum arak adalah hudūd. Tetapi mereka berselisih pendapat pada kadar dan cara pelaksanaan hukuman. Dengan itu ada yang berpendapat bahawa kadar hukuman sebat yang dikenakan ke atas peminum arak adalah $t a^{6} z \bar{\imath} r$ bukannya $h u d \bar{u} d$ kerana tidak ada nas yang jelas menunjukkan bahawa hukuman yang mesti dikenakan ke atas pesalah minum arak ialah 40 sebat tidak lebih tidak kurang. Ada juga riwayat menyatakan 80 sebatan dan ada yang meriwayatkan Rasulullah S.A.W. menggunakan tangan, kasut, pelepah tamar atau kedua-duanya. ${ }^{32}$

Tambahan pula cara pengambilan dadah berbeza dengan arak yang hanya dikenali dengan minum iaitu melalui rongga mulut. Pengambilan dadah pula boleh dilakukan dengan berbagai-bagai cara seperti suntikan, hisap, hidu, atau dicampur sekali dalam makanan atau minuman. Tambahan pula bahaya dadah jauh lebih teruk berbanding dengan arak. Dengan itu hukuman ke atas pengedar sepatutnya lebih berat setimpal dengan kesalahan. Untuk menentukan hukuman, terpulanglah kepada hakim berdasarkan berat dan seriusnya kesalahan. Untuk mencapai tujuan tersebut kaedah penghukuman ${ }^{6}{ }^{6} z \bar{i} r$ sangatlah bertepatan.

32 'Abd al-'Azīm Syaraf al-Dīn (1973), al-'Uqūbah al-Muqaddarah, li Mașlahati al-Mujtama' al-Islāmī. Mesir: Maktabah al-Kulliyyah al-Azhariyyah, hh. 360-365. 
4. Kalau kita hendak golongkan kesalahan mengedar dadah di bawah had hirābah, penjenayah dikenakan hukuman bunuh apabila dia membunuh mangsa yang dirompaknya. ${ }^{33}$ Di sebaliknya, kesalahan rompakan yang tidak melibatkan pembunuhan penjenayah dikenakan hukuman lain selain daripada hukuman mati. Pengedar dadah pula tidak jelas melakukan pembunuhan ke atas penagih. Mungkin mereka boleh berhujah bahawa penjualan dadah adalah di atas permintaan penagih dengan kerelaan mereka sendiri.

5. Dalam mencari penyelesaian kepada masalah penyalahgunaan dadah dan kemusnahan yang disebabkan olehnya, soal permintaan dan penawaran (demand and supply) di pasaran juga perlu diambil kira kerana kalau tidak ada langsung permintaan bagi bekalan dadah di pasaran nescaya tidak akan ada orang berniaga dadah. Jadi dalam menentukan siapa yang bersalah, penagih juga turut bersalah melayan nafsu dengan menghancurkan kehidupanmereka. Mereka sanggupmelakukan apa sahaja untuk mendapatkan bekalan dadah demi memuaskan nafsu. Semakin banyak permintaan dan semakin sukar dadah didapati, semakin mahal pulalah harganya. Dengan itu semakin tamak pulalah pengedar dadah. Sekalipun tidak ada bekalan daripada luar, penyakit ketagihan akan mendorong penagih mendapatkan bekalan dadah walaupun terpaksa memproses dadah sendiri. Dengan itu boleh dirumuskan bahawa gejala ini berpunca daripada kedua-dua pihak. Ini jauh berbeza dengan jenayah hirābah yang disebabkan oleh satu pihak sahaja.

\subsection{Kesan Perbezaan Penentuan Hukuman Hudūd Atau Ta $z \bar{z} r$ ke Atas Pengedar Dadah}

Amat penting untuk memastikan sama ada kesalahan mengedar dadah diletak di bawah kesalahan hudūd ataupun ta' $z \bar{\imath} r$. Ini kerana dalam menggolongkan kesalahan mengedar dadah di bawah kesalahan hudud atau $t a^{6} z \bar{l} r$, didapati perbezaan klasifikasi ini menyebabkan hasil hukuman dan implikasi yang berbeza dalam menjatuhkan hukuman. Di antara perbezaan yang ketara ialah:

33 Bahansī, op.cit., h. 180. 
1. Kalau mengikut pendapat mereka yang menggolongkan kesalahan mengedar di bawah hudud iaitu hirābah, kemaafan ke atas hukuman mati oleh pihak pemerintah tidak dibenarkan kerana ia dianggap sebagai hak Allah iaitu hak kepentingan masyarakat keseluruhannya. ${ }^{34}$

2. Di bawah hukuman $t a^{6} z \bar{i} r$, hakim boleh memberi kemaafan ke atas pesalah dan hukuman mati boleh ditarik balik berdasarkan kemașlaḥatan tertentu. Dengan itu pesalah boleh membuat rayuan pengampunan daripada hukuman. Manakala hukuman hudūd pula adalah mandatori di mana hakim mestilah melaksanakan hukuman mati yang ditetapkan kerana ia adalah hak Allah tanpa kemaafan, pengurangan atau pengecualian. ${ }^{35}$

3. Dalam melaksanakan hukuman $t a^{6} z \bar{\imath} r$, tidak semestinya setiap penjenayah menerima hukuman yang sama rata. Ini berbeza dengan hukuman hudūd yang mewajibkan setiap pesalah dikenakan hukuman yang sama. ${ }^{36}$ Sebagai contoh, seorang pencuri yang mencuri RM 1000 mendapat hukuman yang sama dengan pencuri RM100,000. Kedua-duanya mesti dikenakan hukuman potong tangan apabila disabitkan kesalahan. Walaupun hakim boleh menambah hukuman $t a^{6} z \bar{i} r$ di samping hukuman hudūd bagi jenayah yang serius, kita perlu melihat kepada konsep menjaga amanah dan menghormati hak orang lain yang sangat dipandang tinggi oleh Syarak. Sementara perbuatan khianat sangatlah hina walaupun dengan nilai yang tidak seberapa dengan itu dikenakan juga hukuman potong tangan. ${ }^{37}$ Tambahan pula nilai RM 1000 sangatlah tinggi bagi orang miskin, pada masa yang sama ia tidak berapa bermakna bagi golongan kaya. Ketetapan ini mempunyai hikmat yang tersendiri yang dikehendaki oleh Syarak. Samalah juga dengan kesalahan mengedar dadah, kalaulah digolongkan di bawah kesalahan hudūd ia bererti semua pesalah yang melebihi had milikan tertentu mestilah dikenakan hukuman yang sama iaitu hukuman mandatori.

34 'Abd al-Qadir 'Audah, op.cit., jil. 1, h. 468.

35 Sāmih al-Sayyid Jad, op.cit., h. 70.

36 Namlah, op.cit., h. 398.

37 Nilai nisab yang paling rendah bagi hukuman potong tangan ialah $1 / 4$ Dinar. Sila lihat Haji Said bin Haji Ibrahim, Kanun Jenayah Syar'iyyah, h. 109. 
4. Hukuman $t a^{6} z \bar{\imath} r$ boleh dikenakan ke atas kanak-kanak yang didapati bersalah melakukan apa-apa larangan atau meniggalkan suruhan Syarak dengan hukuman yang sepadan dengan umur dan berat kesalahan bagi tujuan mendidik. Di sebaliknya hukuman hudūd dikecualikan ke atas kanak-kanak yang tidak sampai umur. Ini kerana di antara syarat utama hukuman hudūd ialah baligh dan berakal. ${ }^{38}$

Dengan itu, kesalahan mengedar dadah yang dilakukan oleh remaja di bawah umur boleh dikenakan hukuman tertentu sebagai ta' $z \bar{r}$ r supaya dia merasai keperitan hukuman dan tidak akan mengulangi lagi perbuatan terkutuk itu.

\section{RUMUSAN}

Berdasarkan perbincangan di atas, bolehlah dirumuskan bahawa hukuman mati mandatori ke atas pengedar dadah di Malaysia menyamai hukuman hudūd daripada sudut ketegasan hukuman dan kesamarataan hukuman mati ke atas setiap pesalah yang disabitkan dengan kesalahan mengedar dadah yang melibatkan hukuman mati. Dengan itu tidak timbul soal ketidakadilan hakim dalam menjatuhkan hukuman yang sama ke atas penjenayah iaitu hukuman mati. Kesalahan hudūd yang dimaksudkan ialah had hirābah. Iaitu peruntukan hukuman mati ke atas mereka yang melakukan rompakan, kekacauan dan kerosakan di atas muka bumi.

Hukuman mati mandatori ke atas pengedar dadah di Malaysia mengandungi unsur-unsur hudūd dan $t a^{6} z \bar{\imath} r$. Soal adakah rayuan keampunan bercanggah dengan Islam tidak timbul kerana sekalipun ia diletakkan di bawah hudūd, konsep rayuan dalam hudūd juga dibenarkan bagi mempertikaikan sabitan kes dan kekeliruan keterangan (syubhah). Tetapi, rayuan untuk melepaskan diri daripada hukuman atau mendapat keampunan tidak dibolehkan sama sekali di dalam hudūd.

Penulis berpendapat hukuman mati mandatori ke atas pengedar dadah di Malaysia lebih menepati $t a^{6} z \bar{\imath} r$. Walaupun pesalah mendapat hukuman yang sama rata dalam penghukuman

38 al-Ghāmidī (1992), op.cit., h. 30. 
iaitu hukuman mati, hukuman itu ditetapkan berdasarkan kepada keparahan jenayah yang munasabah. Ia juga bertujuan untuk mengelakkan tuduhan ketidakadilan hakim dalam menjatuhkan hukuman.

Walaupun hukuman mati mandatori ke atas pengedar dadah tidak menepati hukuman hudūd atau $t a^{6} z \bar{\imath} r$ keseluruhannya, agak sukar bagi kita untuk mengatakan yang ia bertentangan dengan Islām. Ini kerana berdasarkan konsep al-siyāsah al-syar'iyyah yang mengambil kira kemaslahatan umum yang mana tidak ada jalan lain untuk menyelesaikan satu-satu fitnah dan kehancuran kepada umat, pemerintah dibolehkan menggubal polisi undangundang tertentu untuk mengawalnya. ${ }^{39}$

Di dalam kaedah al-siyāsah al-syar'iyyah, tidak ada dalil bukan bererti tidak ada hukum. Tidak ada dalil daripada al-Qur'an, hadis, ijma' atau qiyās bagi sesuatu peristiwa atau masalah tidak menunjukkan bahawa tidak boleh dikenakan hukuman atau tindakan undang-undang langsung. Di sebaliknya, sesuatu undangundang itu dianggap bercanggah dengan Islam apabila ada dalil khusus melarangnya atau ternyata ia bertentangan dengan konsep menjaga mașlahah yang lima (agama, akal, nyawa, harta dan keturunan) atau bercanggah dengan kaedah-kaedah Syariah yang umum. ${ }^{40}$

Syeikh 'Abd al-'Āl 'Atwah berpendapat bahawa menggubal sesuatu hukuman yang berat bagi kesalahan tertentu apabila kemaslahatan umum sangat memerlukannya dikira termasuk dalam kaedah al-siyāsah al-syar'iyyah. Ia tidak bercanggah dengan Syarak walaupun tidak ada dalil khusus baginya. Tindakan ini dipanggil al-siyāsah al-syar'iyyah kerana ia dapat merealisasikan matlamat Syariah iaitu mengelakkan kehancuran dan kemusnahan dalam masyarakat melalui hukuman yang tidak diperuntukkan di bawah kesalahan hudūd atau kesalahan ta'zìr yang ditentukan oleh pemerintah sebelumnya. ${ }^{41}$

39 'Abd al-'Āl Aḥmad 'Ațwah, al-Madkhal ilāal-Siyāsahal-Syar'iyyah, hh. 58-60.

40 Ibid., h. 132.

41 Ibid., hh. 82-83. 